\title{
Pheromone of the Banana-Spotting Bug, Amblypelta lutescens lutescens Distant (Heteroptera: Coreidae): Identification, Synthesis, and Field Bioassay
}

\author{
Ashot Khrimian, ${ }^{1}$ Harry A. C. Fay, ${ }^{2}$ Filadelfo Guzman, ${ }^{1}$ Kamlesh Chauhan, ${ }^{1}$ \\ Chris Moore, ${ }^{3}$ and Jeffrey R. Aldrich ${ }^{1}$ \\ ${ }^{1}$ Beltsville Agricultural Research Center, Agricultural Research Service, USDA, Building 007, Room 326, BARC-West, \\ 10300 Baltimore Avenue, Beltsville, MD 20705, USA \\ ${ }^{2}$ Department of Employment, Economic Development and Innovation, Horticulture and Forestry Science, 28 Peters Street, \\ P.O. Box 1054, Mareeba, QLD 4880, Australia \\ ${ }^{3}$ School of Biological Sciences, The University of Queensland, Brisbane, QLD 4072, Australia
}

Correspondence should be addressed to Ashot Khrimian, ashot.khrimian@ars.usda.gov

Received 14 February 2012; Accepted 21 April 2012

Academic Editor: Jocelyn G. Millar

Copyright ( $) 2012$ Ashot Khrimian et al. This is an open access article distributed under the Creative Commons Attribution License, which permits unrestricted use, distribution, and reproduction in any medium, provided the original work is properly cited.

\begin{abstract}
The banana-spotting bug, Amblypelta lutescens lutescens Distant (Heteroptera: Coreidae), is one of the principal pests of tree fruits and nuts across northern and eastern Australia. Apart from visual damage assessment, there are currently no reliable methods for monitoring bug activity to aid management decisions. An attractant pheromone for this species that could be used as a trap lure could potentially fill this void. Earlier, two male-specific compounds were identified in airborne extracts from A. lutescens lutescens, $(E, E)$ - $\alpha$-farnesene and $(R, E)$-nerolidol; an unknown compound with a molecular weight 220 was also detected. We now report the identification of this hitherto unknown compound as $(R, E, E)-\alpha$-farnesene-10,11-oxide. Synthesis of this epoxide was conducted using a regioselective asymmetric dihydroxylation of a sulfolene. A blend mimicking the natural proportions of $(E, E)-\alpha$-farnesene, $(R, E)$-nerolidol, and $(R, E, E)$ - $\alpha$-farnesene-10,11-oxide attracted male and female A. lutescens lutescens as well as nymphs in the field, verifying that the aggregation pheromone comprises or is contained within this group of compounds.
\end{abstract}

\section{Introduction}

The fruit-spotting bug, Amblypelta lutescens lutescens Distant (Heteroptera: Coreidae), commonly known as the bananaspotting bug, is one of the most important insect pests of fruit and nut crops in tropical and subtropical Australia [1-4]. Nymphs and adults feed on shoots and developing fruits of a wide range of commercial tree crops, causing significant production losses if pesticides are not regularly applied. Monitoring banana-spotting bug activity in crops is extremely difficult and currently relies on scouts assessing damage at weekly or fortnightly intervals throughout the season [5]. This approach is reactive and not always effective, as well as being time consuming and expensive since a large proportion of a crop must be monitored because damage can be unevenly distributed throughout an orchard. Alternative monitoring tools based on semiochemicals, such as host plant volatiles and/or pheromones, are highly desirable because they could potentially be more reliable and easier to standardize. Studying male-specific compounds from Nearctic and Australasian true bugs, Aldrich et al. identified $(E, E)$ - $\alpha$-farnesene and $(R, E)$-nerolidol from $A$. lutescens lutescens, whereas a third compound with molecular weight 220 remained unknown [6]. Blends of these chemicals could serve as an attractant pheromone for A. lutescens lutescens but their biological importance has not been demonstrated, nor has the structure of the unknown compound been elucidated. The aims of this paper were to address both of these issues. 


\section{Material and Methods}

2.1. Insects. Amblypelta lutescens lutescens males were handcollected from a row of Murraya paniculata (orange jessamine) bushes on the northwest outskirts of Mareeba, Australia $\left(16^{\circ} 59^{\prime} \mathrm{S}, 145^{\circ} 25^{\prime} \mathrm{E}\right)$, at the end of March 2009. Males were separated from females by the squarer shape of the tip of the abdomen when viewed laterally. The collected males were held in a $30 \times 30 \times 30 \mathrm{~cm}$ gauze-covered cage with $M$. paniculata fruit, green beans, and water at approximately $26^{\circ} \mathrm{C}$ and $60-70 \% \mathrm{RH}$ under natural light until aeration experiments.

2.2. Collection of Airborne Volatiles from Males. Two samples of airborne extracts were collected in Mareeba from 14 male A. lutescens lutescens over a 4- and then a 3-day period in early April 2009. During aerations, the males were held in a $500 \mathrm{~mL}$ triple-neck vacuum flask with 3 green beans as food. The flask inlet was connected by silicone tubing ( $8 \mathrm{~mm}$ i.d.) to a modified Pasteur pipette ( $5 \mathrm{~mm}$ i.d.) containing $50 \mathrm{~mm}$ of acid-cleansed activated charcoal to filter the incoming air. The flask outlet was also connected by silicone tubing to an $18 \mathrm{~cm}$ long glass tube ( $5 \mathrm{~mm}$ i.d.) containing $50 \mathrm{~mm}$ of Super Q absorbent (Alltech, USA) held in place on each end by glass wool. Silicone tubing connected the glass tube to an Airchek 224-PCXR8 Sampler pump (SKC Inc., Eight-Four PA), which operated at $250-500 \mathrm{~mL} / \mathrm{min}$ during the aerations. All connections in the inlet and outlet lines were sealed with Teflon tape. Sampling was conducted at approximately $26^{\circ} \mathrm{C}$ and $60-70 \% \mathrm{RH}$. No bugs died during either sampling period. Once collected, the aeration samples in their glass tubes were sealed in individual airtight containers and sent to USDA-ARS, Beltsville, where they were eluted with $600 \mu \mathrm{L}$ of hexane. The extracts were concentrated to $50 \mu \mathrm{L}$ under a gentle stream of $\mathrm{N}_{2}$ and analyzed by gas chromatographymass spectrometry (GC-MS) on an Rtx-5MS and by GC on Chiraldex B-DM columns (see below).

2.3. Analytical Methods. Electron-impact (EI) mass spectra were obtained at $70 \mathrm{eV}$ with an Agilent Technologies 5973 mass selective detector interfaced with a $6890 \mathrm{~N}$ GC equipped with a $30 \mathrm{~m} \times 0.25 \mathrm{~mm}$ i.d. $\times 0.25 \mu \mathrm{m}$ film Rtx-5MS (Restek Corporation, Bellefonte, PA, USA) column. Column temperature was maintained at $50^{\circ} \mathrm{C}$ for $5 \mathrm{~min}$ and then raised to $260^{\circ} \mathrm{C}$ at $10^{\circ} \mathrm{C} / \mathrm{min}$. Helium was used as a carrier gas at $1 \mathrm{~mL} / \mathrm{min}$. Enantioselective GC analyses of nerolidol and racemic and optically active $(E, E)-\alpha$-farnesene oxide were performed on an Agilent Technologies 6890 N GC equipped with an FID detector and $30 \mathrm{~m} \times 0.25 \mathrm{~mm}$ i.d. $\times 0.12 \mu \mathrm{m}$ film Chiraldex B-DM column (Astec, Whippany, NJ, USA). Column temperature was maintained at $100^{\circ} \mathrm{C}$ for $2 \mathrm{~min}$ and then raised to $180^{\circ} \mathrm{C}$ at $2^{\circ} \mathrm{C} / \mathrm{min}$. Hydrogen was used as a carrier gas at $1 \mathrm{~mL} / \mathrm{min} .{ }^{1} \mathrm{H}$ and ${ }^{13} \mathrm{C}$ NMR spectra of compounds 6 and 8 were obtained on a Bruker AVIII- $600 \mathrm{MHz}$ spectrometer. ${ }^{1} \mathrm{H}$ NMR spectra of compounds $\mathbf{4}$ and $\mathbf{1 0}$ and ${ }^{1} \mathrm{H}-{ }^{1} \mathrm{H}$ COSY of 6 were obtained on a Bruker AV-400 MHz spectrometer. The ${ }^{1} \mathrm{H}$ NMR spectrum of compound 5 was obtained on an Anasazi $90 \mathrm{MHz}$ spectrometer (Indianapolis, IN). Chemical shifts are reported in $\delta$ units and referenced to the residual $\mathrm{CDCl}_{3}$ solvent signal. Optical rotations were obtained on a Perkin-Elmer 241 polarimeter with a $1.0 \mathrm{~mL}$ cell. Thin layer chromatography analyses were conducted on Whatman AL SIL G/UV plates using 20\% ethanol solution of phosphomolybdic acid and/or UV for visualization of spots. Flash chromatography was carried out with 230-400 mesh silica gel (Fisher Scientific, Fair Lawn, NJ).

2.4. Chemicals. All reagents and solvents were purchased from Aldrich Chemical Co. (Milwaukee, WI) unless otherwise specified. Hexamethylphosphoramide (HMPA, highly toxic) was distilled from $\mathrm{P}_{2} \mathrm{O}_{5}$, and tetrahydrofuran (THF) was dried by distillation from sodium benzophenone-ketyl. $(R, E)$-Nerolidol was synthesized from $(E, E)$-farnesol using a four-step procedure described by Kigoshi et al. [7] that involved a Sharpless-Katsuki asymmetric epoxidation, conversion of the resulting $(2 R, 3 R)$-epoxyfarnesol to a tosylate and further to $(2 R, 3 R)$-epoxyfarnesyl iodide, and, finally, a stereoselective zinc reduction of the latter. The enantiomeric purity of $(R, E)$-nerolidol, as judged from GC analysis on a Chiraldex B-DM column, was 93\% (see Section 2.3 for GC conditions). Racemic (E,E)- $\alpha$-farnesene oxide $(r a c-4)$ was prepared by epoxidation of $(E, E)$ - $\alpha$-farnesene with $m$-chloroperbenzoic acid (MCPBA) as described in Spicer et al. [8].

2.4.1. (E)- 2-(3',7'-Dimethylocta-2', $6^{\prime}$-dienyl)-3-methyl-2,5dihydrothiophene-1,1-dioxide (5). Procedures of Yamada et al. [9] and Desai et al. [10] were followed. 3-Methyl2,5-dihydrothiophene-1,1-dioxide (3-methyl-3-sulfolene, $10.95 \mathrm{~g}, 82.84 \mathrm{mmol}$, Alfa Aesar, Ward Hill, MA; recrystallized from methanol before use) was placed under $\mathrm{N}_{2}$ into a four-neck round bottomed flask equipped with a thermometer, mechanical stirrer, dropping funnel, $\mathrm{N}_{2}$ inlet, and a septum. Dry THF $(300 \mathrm{~mL})$ was added; the solution was cooled to $-72^{\circ} \mathrm{C}$ and then charged sequentially with geranyl bromide $(9.0 \mathrm{~g}, 41.44 \mathrm{mmol})$ and anhydrous hexamethylphosphoramide (HMPA, $29 \mathrm{~mL}$ ). Lithium bis(trimethylsilyl)amide $(41.4 \mathrm{mmol} ; 41.4 \mathrm{~mL}$ of $1.0 \mathrm{M}$ in THF) was added slowly under vigorous stirring, maintaining the temperature below $-68^{\circ} \mathrm{C}$. The reaction mixture was stirred for $30 \mathrm{~min}$ at $-70^{\circ} \mathrm{C}$, then slowly warmed to $-20^{\circ} \mathrm{C}$, and quenched with ethyl acetate $(150 \mathrm{~mL})$. The mixture was concentrated on a rotary evaporator, and the residue was dissolved in ether $(500 \mathrm{~mL})$, washed with water and brine, and then dried over anhydrous sodium sulfate. Evaporation of the solvent and flash chromatography of the residue with hexane/ethyl acetate $(3: 1)$ yielded compound 5 ( $9.30 \mathrm{~g}, 84 \%$ from geranyl bromide). GC-MS analysis of 5 proceeded with complete extrusion of $\mathrm{SO}_{2}$ as described in Chou et al. [11] resulting in $(E, E)$ - $\alpha$-farnesene of $95 \%$ purity. GC-MS $(\mathrm{m} / z$, $\%): 204\left(\mathrm{M}^{+}, 1\right), 189(2), 161(5), 133(5), 123$ (33), 119 (38), 107 (46), 105 (24), 93 (100), 91 (38), 81 923), 80 (24), 79 (45), 77 (28), 69 (58), 67 (12), 55 (50), 53 (17), 43 (16), 41 (69). The mass spectral data matched those reported in NIST 08 MS Library for $(E, E)-\alpha$-farnesene. ${ }^{1} \mathrm{H}$ NMR $(90 \mathrm{MHz}$, $\left.\mathrm{CDCl}_{3}\right): 1.58$ (br s, $\left.3 \mathrm{H}\right), 1.62$ (br s, $\left.6 \mathrm{H}\right), 1.82(\mathrm{~m}, 3 \mathrm{H})$, $1.95-2.06(\mathrm{~m}, 4 \mathrm{H}), 2.57$ (br t, $J=7.0 \mathrm{~Hz}, 2 \mathrm{H}), 3.38-3.70(\mathrm{~m}$, $3 \mathrm{H}), 5.06(\mathrm{~m}, 1 \mathrm{H}), 5.20(\mathrm{br} \mathrm{t}, J=7.0 \mathrm{~Hz}, 1 \mathrm{H}), 5.62(\mathrm{~m}, 1 \mathrm{H})$. Data are in good agreement with those reported in [8]. 
2.4.2. (3E,6E)-3,7,11-Trimethyl-1,3,6,10-dodecatetraene $((E, E)$ - $\alpha$-Farnesene 2). (E,E)- $\alpha$-Farnesene was prepared by thermal decomposition of $5(100 \mathrm{mg}, 0.37 \mathrm{mmol})$ in degassed refluxing $n$-octane $(5 \mathrm{~mL})$ bubbled with $\mathrm{N}_{2}$ for $1.5 \mathrm{~h} \mathrm{[12].} \mathrm{The} \mathrm{solution} \mathrm{was} \mathrm{cooled,} \mathrm{concentrated,} \mathrm{and}$ purified by flash chromatography with pentane to give 2 (61 mg, 81\%) of $94 \%$ purity.

2.4.3. (2R/S, $\left.6^{\prime} S, 2^{\prime} E\right)-2-\left(3^{\prime}, 7^{\prime}\right.$-Dimethyl $-6^{\prime}, 7^{\prime}-$ dihydroxy $-2^{\prime}-$ octenyl)-3-methyl-2,5-dihydrothiophene-1,1-dioxide (6). A procedure by Sharpless et al. [13] was followed. AD-mix $\alpha$ $(26.0 \mathrm{~g})$ was added to a stirred mixture of $t-\mathrm{BuOH}(83 \mathrm{~mL})$ and water $(93 \mathrm{~mL})$ at $0-5^{\circ} \mathrm{C}$. Methanesulfonamide $(1.70 \mathrm{~g}$, $17.90 \mathrm{mmol}$ ) was added, followed by sulfolene $5(5.0 \mathrm{~g}$, $18.62 \mathrm{mmol}$ ). The mixture was stirred for $8 \mathrm{~h}$, after which TLC analysis (hexane/ethyl acetate, $1: 3$ ) showed very little remaining starting material. Sodium sulfite $(2.35 \mathrm{~g})$ was added, and the mixture was allowed to warm to room temperature. The mixture was diluted with water $(40 \mathrm{~mL})$ and extracted with dichloromethane $(6 \times 50 \mathrm{~mL})$. The organic extracts were combined, dried with $\mathrm{Na}_{2} \mathrm{SO}_{4}$, and concentrated. Flash chromatography with hexane/ethyl acetate $(1: 3)$ provided diol $6(4.96 \mathrm{~g}, 88 \%)$ as a mixture of two diastereomers in about equal quantity. GC-MS $(\mathrm{m} / \mathrm{z}$, \%): 179 (3), 159 (3), 134 (28), 121 (24), 119 (55), 107 (28), 93 (66), 91 (40), 81 (67), 80 (58), 79 (47), 59 (100), 43 (47), $41(42) \cdot[\alpha]_{\mathrm{D}}{ }^{25}=-9.26^{\circ}\left(\right.$ c $\left.1.75, \mathrm{CHCl}_{3}\right) \cdot{ }^{1} \mathrm{H} \mathrm{NMR}$ $\left(600 \mathrm{MHz}, \mathrm{CDCl}_{3}\right): 1.149$ and $1.154\left(\mathrm{~s}, 3 \mathrm{H}, \mathrm{C}^{\prime}-\mathrm{CH}_{3} \mathrm{~A}\right)$, 1.19 and $1.20\left(\mathrm{~s}, 3 \mathrm{H}, \mathrm{C}^{\prime}-\mathrm{CH}_{3} \mathrm{~B}\right), 1.44\left(\mathrm{~m}, 1 \mathrm{H}, \mathrm{H}-5^{\prime}\right), 1.62$ $\left(\mathrm{m}, 1 \mathrm{H}, \mathrm{H}-5^{\prime}\right), 1.68$ and $1.69\left(\mathrm{~s}, 3 \mathrm{H}, \mathrm{C}^{\prime}-\mathrm{CH}_{3}\right), 1.86(\mathrm{br}$ s, $\left.3 \mathrm{H}, \mathrm{C} 3-\mathrm{CH}_{3}\right), 2.13-2.28\left(\mathrm{~m}, 4 \mathrm{H}, \mathrm{H}-4^{\prime}, 2 \mathrm{OH}\right), 2.57(\mathrm{~m}$, $\left.2 \mathrm{H}, \mathrm{H}-1^{\prime}\right), 3.35\left(\mathrm{t}, J=10.2 \mathrm{~Hz}, 1 \mathrm{H}, \mathrm{H}-6^{\prime}\right), 3.55-3.75(\mathrm{~m}$, $3 \mathrm{H}, \mathrm{H}-2, \mathrm{H}-5), 5.29$ and 5.33 (br t $J=6.5 \mathrm{~Hz}, 1 \mathrm{H}, \mathrm{H}-2^{\prime}$ ), 5.69 (br s, $3 \mathrm{H}, \mathrm{H}-4) .{ }^{13} \mathrm{C}$ NMR $\left(151 \mathrm{MHz}, \mathrm{CDCl}_{3}\right)$ : 15.97, $16.12,17.95,18.02,23.36,23.39,25.98,26.00,26.27,26.30$, $28.61,29.17,36.52,36.67,43.40,55.73,67.25,67.44,72.96$, $77.52,117.16,117.18,119.04,119.27,138.26,138.33,138.69$, 138.80 .

2.4.4. (2R/S, $\left.6^{\prime} R, 2^{\prime} E\right)-2-\left(3^{\prime}, 7^{\prime}\right.$-Dimethyl- $6^{\prime}, 7^{\prime}$-dihydroxy2'-octenyl)-3-methyl-2,5-dihydrothiophene-1,1-dioxide (7). Analogous to the procedure described above, sulfolene $\mathbf{5}$ $(1.498 \mathrm{~g}, 5.58 \mathrm{mmol})$ was dihydroxylated with $\mathrm{AD}$-mix $\beta$ $(7.79 \mathrm{~g})$ in the presence of methanesulfonamide $(0.53 \mathrm{~g}$, $5.58 \mathrm{mmol})$ in a mixture of $t-\mathrm{BuOH}(27 \mathrm{~mL})$ and water $(27 \mathrm{~mL})$ to give diol $7(1.200 \mathrm{~g}, 71 \%) \cdot[\alpha]_{\mathrm{D}}{ }^{25}=+10.49^{\circ}(c$ 2.64, $\left.\mathrm{CHCl}_{3}\right)$.

2.4.5. (3S,6E,9E)-2,6,10-trimethyl-6,9,11-dodecatriene-2,3diol (8). A two-neck conical flask equipped with a reflux condenser and $\mathrm{N}_{2}$ inlet extending to the bottom of the flask was loaded with a mixture of sulfolenediol 6 (491 mg, $1.62 \mathrm{mmol})$ and pyridine $(10 \mathrm{~mL})$. The solution was degassed with a gentle steam of $\mathrm{N}_{2}$ for $10 \mathrm{~min}$ and then heated in an oil bath at $122^{\circ} \mathrm{C}$ while maintaining the $\mathrm{N}_{2}$ flow. After $2 \mathrm{~h}$ of heating, TLC (hexane/ethyl acetate, $1: 3$ ) showed that the reaction was almost complete. The solution was concentrated by rotary evaporation, and the remainder was purified by flash chromatography with (hexane/ethyl acetate, $1: 1$ ) to provide diol 8 ( $287 \mathrm{mg}, 74 \%)$. GC-MS ( $\mathrm{m} / \mathrm{z}, \%): 205$ (1), 179 (5), 159 (5), 143 (7), 134 (40), 121 (32), 119 (71), 107 (33), 105 (37), 93 (72), 91 (43), 81 (74), 80 (66), 79 (48), 59 (100), $43(31), 41(26) \cdot[\alpha]_{\mathrm{D}}{ }^{25}=-23.9^{\circ}\left(c 2.70, \mathrm{CHCl}_{3}\right)$. Lit. [14] $[\alpha]_{\mathrm{D}}=-20.8^{\circ}\left(c 0.03, \mathrm{CHCl}_{3}\right) .{ }^{1} \mathrm{H} \mathrm{NMR}\left(600 \mathrm{MHz}, \mathrm{CDCl}_{3}\right)$ : 1.16 (s, H-1), 1.21 (s, 3H, C2- $\left.\mathrm{CH}_{3}\right), 1.60$ (m, 2H, H-4), 1.66 $(\mathrm{s}, 3 \mathrm{H}), 1.77(\mathrm{~s}, 3 \mathrm{H}), 2.09(\mathrm{~m}, 1 \mathrm{H}, \mathrm{H}-5 \mathrm{~A}), 2.27(\mathrm{~m}, 1 \mathrm{H}, \mathrm{H}-$ 5B), $2.86(\mathrm{t}, J=7.2 \mathrm{~Hz}, 2 \mathrm{H}, \mathrm{H}-8), 3.36(\mathrm{~m}, 1 \mathrm{H}, \mathrm{H}-3), 4.94$ $(\mathrm{d}, J=10.8 \mathrm{~Hz}, 1 \mathrm{H}, \mathrm{H}-12$ cis $), 5.10(\mathrm{~d}, J=17.4 \mathrm{~Hz}, 1 \mathrm{H}, \mathrm{H}-$ 12 trans), $5.20(\mathrm{t}, J=6.0 \mathrm{~Hz}, 1 \mathrm{H}, \mathrm{H}-7), 5.45(\mathrm{t}, J=7.5 \mathrm{~Hz}$, $1 \mathrm{H}, \mathrm{H}-9), 6.36$ (dd, $J=17.4,10.8 \mathrm{~Hz}, 1 \mathrm{H}, \mathrm{H}-11) .{ }^{13} \mathrm{C}$ NMR $\left(151 \mathrm{MHz}, \mathrm{CDCl}_{3}\right): 11.9,16.3,23.31,26.7,27.4,29.9,36.9$, 73.3, 78.5, 110.9, 122.9, 131.6, 134.1, 135.9, 141.7. ${ }^{1} \mathrm{H}$ NMR data are in close agreement with reported values [14].

2.4.6. (3R,6E,9E)-2,6,10-Trimethyl-6,9,11-dodecatriene-2,3diol (9). Analogously to the preparation of diol 8, sulfolenediol $7(1.250 \mathrm{~g}, 4.13 \mathrm{mmol})$ was heated in the presence of pyridine (50 mL) to provide diol 9 (546 mg, 55\%, 98\% pure). The mass spectrum of $\mathbf{9}$ was identical to that of $8 .[\alpha]_{\mathrm{D}}{ }^{25}=$ $+25.0^{\circ}$ (c 2.58, $\left.\mathrm{CHCl}_{3}\right)$. Lit. [14] $[\alpha]_{\mathrm{D}}=+21.2^{\circ}($ c 0.05 , $\left.\mathrm{CHCl}_{3}\right)$.

2.4.7. (10R,3E,6E)-3,7,11-Trimethyl-10,11-epoxy-1,3,6-dodecatriene ((R,E,E)- $\alpha$-farnesene-10,11-oxide, 4). Methanesulfonyl chloride $(138 \mu \mathrm{L}, 1.73 \mathrm{mmol})$ was added to a solution of diol $8(378 \mathrm{mg}, 1.59 \mathrm{mmol})$ in dry pyridine $(2 \mathrm{~mL})$ at room temperature. After stirring for $1 \mathrm{~h}$, TLC (hexane/ethyl acetate, $1: 1$ ) confirmed a complete conversion of the diol to the secondary mesylate. The mixture was cooled in an ice bath and quenched with a mixture of water $(3 \mathrm{~mL})$ and methyl $t$-butyl ether $(3 \mathrm{~mL})$. The organic layer was separated, and the aqueous layer was extracted with methyl $t$-butyl ether $(5 \times 3 \mathrm{~mL})$. The organic extracts were combined, dried over $\mathrm{Na}_{2} \mathrm{SO}_{4}$, and concentrated. The crude mesylate (still containing pyridine) was dissolved in methanol (5 mL) and treated with a solution of $\mathrm{KOH}(162 \mathrm{mg}, 2.89 \mathrm{mmol})$ in $\mathrm{MeOH}(1.5 \mathrm{~mL})$ at $20^{\circ} \mathrm{C}$. A precipitate formed almost instantaneously, and an additional $3 \mathrm{~mL}$ of $\mathrm{MeOH}$ was added to enable stirring for another $30 \mathrm{~min}$. The methanol then was removed in vacuo, and the residue was partitioned between ice water $(3 \mathrm{~mL})$ and ether $(5 \mathrm{~mL})$. The organic layer was separated, and the aqueous layer was extracted with hexane/ether $(1: 1)$. The combined organic extracts were washed with ammonium chloride solution, dried, and concentrated. The remainder was purified by flash chromatography (hexane/ethyl acetate, $1: 1$ ) to provide epoxide $4(223 \mathrm{mg}, 64 \%)$ of $93 \%$ chemical and $95 \%$ enantiomeric purities. The latter was determined by chiral GC analysis on the Chiraldex B-DM column (see Section 2.3 for conditions). $[\alpha]_{\mathrm{D}}{ }^{25}=+0.2^{\circ}\left(c 1.45, \mathrm{CHCl}_{3}\right)$. GC-MS $(\mathrm{m} / \mathrm{z}, \%): 205(1)$, 187 (2), 159 (4), 134 (40), 119 (100), 107 (26), 105 (45), 93 (83), 91 (63), 81 (57), 80 (75), 79 (70), 77 (39), 59 (43), 55 (44), 43 (56), 41 (61). The mass spectral data matched those of the natural epoxide 4 and synthetic racemic epoxide [15]. ${ }^{1} \mathrm{H}$ NMR (400 MHz, $\mathrm{CDCl}_{3}$ ): 1.26 (s, 3H, H-12/C11$\left.\mathrm{CH}_{3}\right), 1.30$ (s, 3H, H-12/C11- $\mathrm{CH}_{3}$ ), 1.67 (br s, $\left.3 \mathrm{H}\right), 1.58-$ $1.75(\mathrm{~m}, 2 \mathrm{H}), 1.77(\mathrm{br} \mathrm{s}, 3 \mathrm{H}), 2.07-2.22(\mathrm{~m}, 2 \mathrm{H}), 2.71(\mathrm{t}$, $J=6.0 \mathrm{~Hz}, 1 \mathrm{H}, \mathrm{H}-10), 2.85($ br t $, J=7.2 \mathrm{~Hz}, 2 \mathrm{H}, \mathrm{H}-5)$, 
$4.94(\mathrm{~d}, J=10.8 \mathrm{~Hz}, 1 \mathrm{H}, \mathrm{H}-1$ cis $), 5.10(\mathrm{~d}, J=17.6 \mathrm{~Hz}$, 1H, H-1 trans), $5.18(\mathrm{dq}, J=7.2,1.2 \mathrm{~Hz}, 1 \mathrm{H}), 5.46(\mathrm{br} \mathrm{t}$, $J=7.2,1 \mathrm{H}), 6.37$ (dd, $J=17.6,10.8 \mathrm{~Hz}, 1 \mathrm{H}, \mathrm{H}-2)$. These data are in good agreement with those previously reported for the racemic epoxide $[8,15]$.

2.4.8. (10S,3E,6E)-3,7,11-Trimethyl-10,11-epoxy-1,3,6-dodecatriene ((S,E,E)- $\alpha$-farnesene oxide, 10). Diol 9 (490 mg, $2.06 \mathrm{mmol}$ ) was mesylated with methanesulfonyl chloride $(179 \mu \mathrm{L}, 2.25 \mathrm{mmol})$ in dry pyridine $(2.5 \mathrm{~mL})$ as described above, and the crude mesylate was treated with $\mathrm{KOH}$ (233 mg) in $10 \mathrm{~mL} \mathrm{MeOH}$ to yield epoxide 10 (222 mg, 50\%) of $92 \%$ of chemical and $94 \%$ enantiomeric purities. $[\alpha]_{\mathrm{D}}{ }^{25}=$ $-0.1^{\circ}\left(c 2.50, \mathrm{CHCl}_{3}\right)$. The mass spectral and NMR data of 10 were identical to those of 4 .

2.5. Field Trapping. Two treatments were tested in a mango orchard on Southedge Research Station, approximately $50 \mathrm{~km}$ west of Cairns in northeast Queensland, Australia: no.1, $0.2 \mathrm{mg}(E, E)$ - $\alpha$-farnesene (2), $1.2 \mathrm{mg}(R, E)$-nerolidol (3), and $0.6 \mathrm{mg}(R, E, E)$ - $\alpha$-farnesene oxide (4); no. 2, $0.2 \mathrm{mg}$ $(E, E)$ - $\alpha$-farnesene, $1.2 \mathrm{mg}(R, E)$-nerolidol, $0.6 \mathrm{mg}(R, E, E)-\alpha$ farnesene oxide, and $0.6 \mathrm{mg}$ hexyl hexanoate (1). Relative proportions of components in these blends were based on relative areas of peaks in the aeration extract. The pheromone components plus 5\% BHT (butylated hydroxytoluene, or 2,6-di-tert-butyl-4-methylphenol) stabilizer were applied to rubber septa in hexane solutions [16] at Beltsville and shipped to Australia. The test site was located at $16^{\circ} 58^{\prime} \mathrm{S}$, $145^{\circ} 20^{\prime} \mathrm{E}$ at an elevation $450 \mathrm{~m}$, and has a mean annual rainfall of $1,110 \mathrm{~mm}$. The station has several thousand mango trees, including an extensive gene pool block, mixed varietal block, a large number of hybrids, and pure blocks containing Kensington Pride, R2E2, and Keitt varieties. The traps were set out in two rows of mature trees (1620 years old) of mixed varieties at one trap per tree with several trees without traps between them. All trees contained maturing fruit at the time of trap deployment in October. Traps consisted of panels of green-colored twin wall polypropylene sheeting (Corflute BFS Plastic Pty. Ltd., Salisbury, QLD, Australia, $0.3 \times 25 \times 30 \mathrm{~cm}$ ), placed 2$2.5 \mathrm{~m}$ above ground and fixed to branches with wire so that they remained rigid even in windy conditions. Traps were covered on each side with double-sided cloth tape coated with emulsion acrylic adhesive (Henkel Aust. Pty. Ltd., Kilsyth, VIC, Australia). Each trap had a $3 \mathrm{~cm}$ diameter hole in the center in which the rubber septum containing the pheromone was fastened. There were five replicates of each pheromone treatment and five untreated control traps. Traps were assigned sequentially for treatments, repeated for each subsequent replicate down the rows. Pheromone lures were stored, sealed, and refrigerated until use, and traps were baited the morning of deployment. Traps were inspected 4 days after their initial deployment, when adult males, females, and nymphs were removed and recorded.

2.6. Analysis of Trapping Data. The data are presented as number of $A$. lutescens lutescens adult males, adult females,

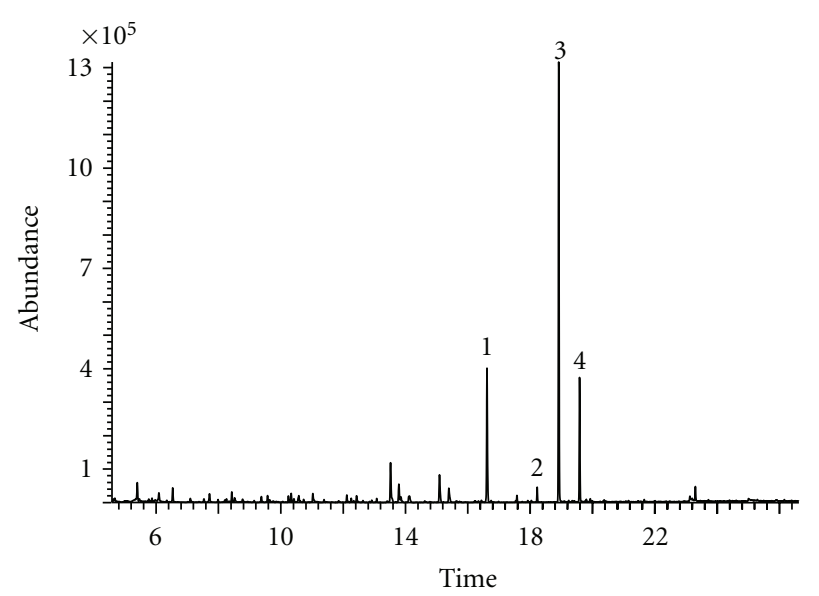

(1) Hexyl hexanoate

(2) $(E, E)-\alpha$-farnesene

(3) $(E)$-nerolidol

(4) $(E, E)-10,11$-epoxy- $\alpha$-farnesene

(a)

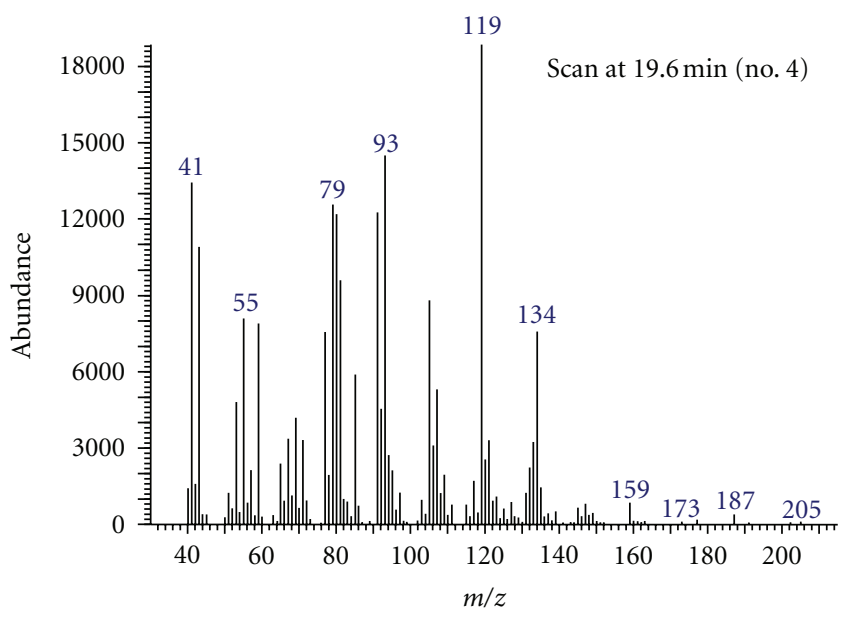

(b)

FIgURE 1: Total ion chromatogram of an aeration extract of male Amblypelta lutescens lutescens and EI mass spectrum of compound 4. Column: Rtx-5MS $(30 \mathrm{~m} \times 0.25 \mathrm{~mm}$ i.d. $\times 0.25 \mu \mathrm{m}), 50^{\circ} \mathrm{C}$ ( $5 \mathrm{~min}$ ) to $260^{\circ} \mathrm{C}$ at $10^{\circ} \mathrm{C} / \mathrm{min}$.

and nymphs per trap per day. Data were $\sqrt{(x+1)}$-transformed to compare treatments by analysis of variance using GenStat 11th Edition [17]. Significantly different means were compared by the least significant difference method at $P=$ 0.05 .

\section{Results and Discussion}

3.1. Identification and Synthesis. The total ion chromatogram (Figure 1) revealed several compounds, among which were the previously identified $(E, E)$ - $\alpha$-farnesene $(2)$ and $(E)$ nerolidol (3) [6], plus compound 4, the mass spectrum of which matched that of the unknown male-specific compound showing a molecular weight 220, previously found by Aldrich et al. [6]. In addition to these compounds, in the aeration sample from males we found a relatively large amount of hexyl hexanoate (1), a trace of which was 


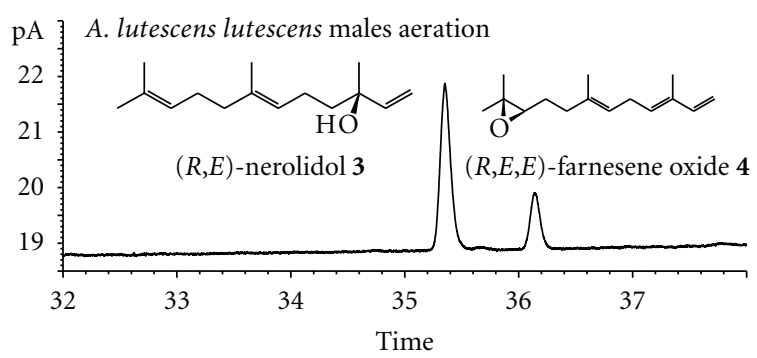

(a)

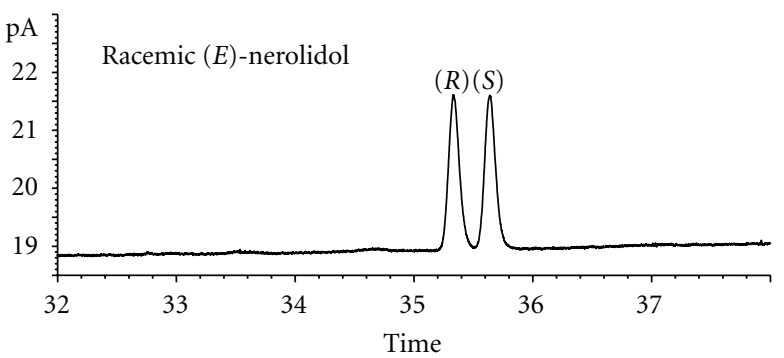

(b)

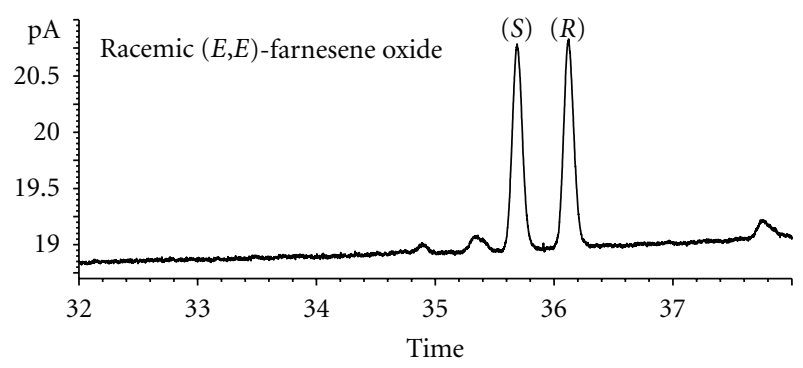

(c)

Figure 2: Sections of GC-FID traces of an aeration extract of male Amblypelta lutescens lutescens (a), racemic (E)-nerolidol (b), and racemic (E,E)-farnesene oxide (c). Column: Chiraldex B-DM $(30 \mathrm{~m}$ $\times 0.25 \mathrm{~mm}$ i.d. $\times 0.12 \mu \mathrm{m}), 100^{\circ} \mathrm{C}(2 \mathrm{~min})$ to $180^{\circ} \mathrm{C}$ at $2^{\circ} \mathrm{C} / \mathrm{min}$.

previously found in female but not male A. lutescens lutescens $[6]$. Because the unidentified compound 4 conceivably could have been an epoxide of $(E, E)$ - $\alpha$-farnesene, we decided to start with a random epoxidation of $(E, E)$ - $\alpha$-farnesene that had already been reported $[8,15]$. We repeated the $m$ chloroperbenzoic acid epoxidation of $(E, E)$ - $\alpha$-farnesene in methylene chloride and found that the monoepoxidation product at the 10,11 double bond matched compound 4 by GC retention time and mass spectrum. The Chiraldex B-DM GC column resolved (Figure 2) synthetic racemic farnesene oxide 4 (lower chromatogram) and racemic $(E)$ nerolidol to baseline (middle chromatogram). Analysis of the A. lutescens lutescens aeration sample of males on the Chiraldex B-DM column (upper chromatogram) revealed that only one enantiomer of $(E)$-nerolidol and farnesene oxide were produced by the bug. Aldrich et al. [6] had already determined that $(E)$-nerolidol produced by $A$. lutescens lutescens had the $(R)$-configuration, and we confirmed this assignment by showing that synthetic $(R, E)$-nerolidol had the same GC retention time as the natural compound, or the first eluting enantiomer of racemic $(E)$-nerolidol.

Determination of the enantiomeric composition of (E,E)- $\alpha$-farnesene-10,11-epoxide 4 produced by A. lutescens lutescens necessitated synthesis of both enantiomers. Thus, we considered a route developed by Moore et al. [18] for synthesis of ocimene epoxides, which was based on a Sharpless asymmetric dihydroxylation and further stereoselective cyclization of intermediate chiral diols to epoxides through secondary mesylates. In fact, asymmetric dihydroxylation of (E,E)- $\alpha$-farnesene 2 had been reported in the literature [14] but only in very low yields (11 and $15 \%$ for $(-)$ and $(+)$ diols, resp.) for a 10,11-dihydroxylation product. The low yield of the desired diol was a reflection of the multiple sites of unsaturation present in $(E, E)$ - $\alpha$-farnesene that were susceptible to asymmetric dihydroxylation. To overcome this shortcoming, we developed a new route presented in Scheme 1, which was essentially an enantioselective version of the synthesis of racemic $(E, E)$ - $\alpha$-farnesene-10,11-epoxide developed by Fielder and Rowan [15]. The synthesis started with alkylation of 3-methyl-3-sulfolene with geranyl bromide, as described in several reports (see Section 2). The key step, asymmetric dihydroxylation of the intermediate 5 with ADmix $\alpha$, was highly regioselective (as was MCPBA epoxidation of 5 [15]) and offered sulfolenediol 6 in $88 \%$ yield. ${ }^{1} \mathrm{H}$ NMR spectrum of diol 6 recorded at $600 \mathrm{MHz}$ clearly shows the presence of two diastereomers with separation of several signals, including $\left(\mathrm{CH}_{3}\right)_{2} \mathrm{COH}$, even though the two chiral centers are separated by five carbon atoms (see Section 2). The observed regioselectivity of asymmetric dihydroxylation of $\mathbf{5}$ was in stark contrast with direct asymmetric dihydroxylation of $(E, E)-\alpha$-farnesene [14] and was similar to the analogous dihydroxylation of ocimene [18] and squalene [19], whereby the reactions occurred primarily at the terminal trisubstituted double bonds.

Thermal elimination of sulfur dioxide in 6 was accomplished in pyridine [10] to minimize side reactions and polymerization due to the acidity of $\mathrm{SO}_{2}$. For the same reason, mesylation of diol $\mathbf{8}$ was also conducted in pyridine, and in the last step, the crude mesylate was cyclized to epoxide 4 with potassium hydroxide in methanol [20]. Analogously, sulfolene 5 was dihydroxylated with $\mathrm{AD}$-mix $\beta$ to provide diol 7, which was then thermally transformed to diol 9. Cyclization of the latter as described above furnished enantiomeric farnesene epoxide 10. Both $\mathbf{4}$ and $\mathbf{1 0}$ were prepared in $\geq 94 \%$ ee as judged by GC analysis on the Chiraldex B-DM column, which indicated that asymmetric dihydroxylation proceeded with high enantioselectivity, as anticipated from the original report by Sharpless et al. [13] and the subsequent results of Moore et al. [18]. High optical purities of epoxides 4 and 10 were also consistent with previous reports [18, 20] and indicative of highly stereoselective, base-catalyzed $\mathrm{S}_{\mathrm{N}} \mathrm{i}$ substitution in the cyclization step. Overall, the route capitalizes on the much higher regioselectivity of dihydroxylation of sulfolene 5 compared to direct dihydroxylation of $(E, E)-\alpha$-farnesene and, in fact, does not add additional steps to the synthesis of diols $\mathbf{8}$ and $\mathbf{9}$ (and epoxides $\mathbf{4}$ and $10)$ because one of the best known synthetic routes to $(E, E)$ $\alpha$-farnesene includes intermediate 5 [11]. 


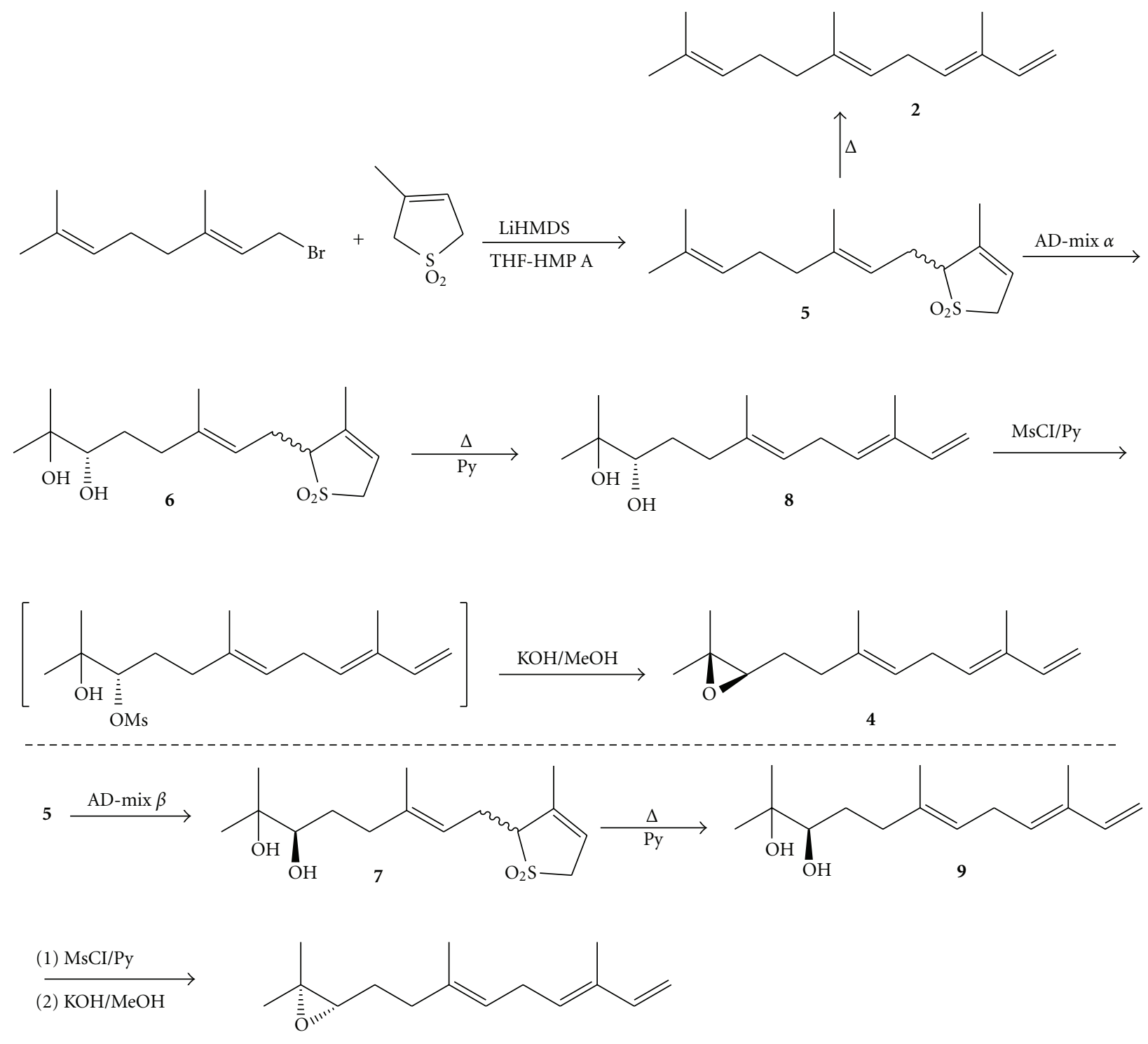

10

Scheme 1: Syntheses of $(R, E, E)$ - and $(S, E, E)$ - $\alpha$-farnesene-10, 11-oxides 4 and 10.

With both enantiomers of farnesene epoxide $\mathbf{4}$ and $\mathbf{1 0}$ available, we identified the later eluting peak in the gas chromatogram of the racemic epoxide on Chiraldex BDM (Figure 2, lower chromatogram) as the (R)-enantiomer and, hence, determined that the natural farnesene epoxide (Figure 2, upper chromatogram) collected from A. lutescens lutescens had the $(R)$-configuration.

3.2. Field Bioassay. In preliminary trapping experiments pheromone lures were deployed on painted plywood panels covered with Tangle-Trap insect barrier gel (The Tanglefoot Co., Grand Rapids, MI, USA). When deployed in avocado and mango orchards, these traps baited with either the 3- or 4-component pheromone lures (see Section 2) only caught 0.01-0.02 A. lutescens lutescens/trap/day. It was observed that many bugs attracted to the pheromone lures were able to escape from the traps unless caught on their backs or sides.
The Corflute panels covered by adhesive tape were much more effective at trapping A. lutescens lutescens and, when deployed with the 3-and 4-component pheromone lures in mangoes, caught up to $0.90 \pm 0.23$ fruit-spotting bugs/trap/day (mean \pm SE) (Table 1). When run in the same trial, the plywood panels with a tangle-trap gel caught a maximum of $0.10 \pm 0.06$ fruit-spotting bugs/trap/day.

There was no statistical difference in the total numbers of A. lutescens lutescens attracted to either the 3- or 4component lures, and traps baited with both caught significantly more bugs than the untreated control traps (Table 1). Thus, hexyl hexanoate does not seem to be a component of the attractant pheromone for A. lutescens lutescens. Both pheromone treatments attracted adult males, adult females, and nymphs, without a clear dominance of one sex or stage over another. Hence, our results indicate that the blend of male-specific compounds $\mathbf{2 - 4}$ found in the male A. lutescens 
TABLE 1: Mean numbers of A mblypelta lutescens lutescens trapped in a mango crop in north Queensland by sticky panels containing 3- and 4-component pheromone lures over a 4-day period in October 2011.

\begin{tabular}{|c|c|c|c|c|c|}
\hline \multirow{3}{*}{ Panel traps } & \multicolumn{4}{|c|}{ Mean no. of A. lutescens lutescens/trap/day $( \pm$ SE $)$} & \multirow{3}{*}{ Total bugs caught } \\
\hline & \multicolumn{2}{|c|}{ Adults } & \multirow{2}{*}{ Nymphs } & \multirow{2}{*}{ Total } & \\
\hline & $0^{7} 0^{x}$ & 우우 & & & \\
\hline 3-component lure & $0.45( \pm 0.16) \mathrm{a}$ & $0.25( \pm 0.08) \mathrm{a}$ & $0.20( \pm 0.09)$ a & $0.90( \pm 0.23) \mathrm{a}$ & 18 \\
\hline 4-component lure & $0.15( \pm 0.10) a b$ & $0.20( \pm 0.05) \mathrm{a}$ & $0.10( \pm 0.06) \mathrm{ab}$ & $0.45( \pm 0.12) \mathrm{a}$ & 9 \\
\hline Untreated control & $0 \mathrm{~b}$ & $0 \mathrm{~b}$ & $0 \mathrm{~b}$ & $0 \mathrm{~b}$ & 0 \\
\hline
\end{tabular}

Means within columns followed by the same letter are not significantly different at $P=0.05$.

lutescens aerations contained the aggregation pheromone for this species. Whereas $(R, E)$-nerolidol had been identified previously from at least two bug species [6] and $(E, E)$ $\alpha$-farnesene was recently identified as a termite alarm pheromone [21], to our knowledge, $(R, E, E)-\alpha$-farnesene10,11-oxide 4 has not been reported as a pheromone component for any other insect species. More research is needed to determine whether the actual pheromone consists of one, two, or all three of these compounds, and for practical purposes, the optimal dose(s) and importance of chirality of the farnesene oxide must be determined. Preliminary experiments have indicated that doubling or tripling the emission rate of the 3-component lure as used above did not increase bug catches. The recent deregistration of endosulfan in Australia has significantly reduced the insecticidal options for the control of A. lutescens lutescens, and an effective monitoring tool based on a pheromone lure may become an essential tool in the management of the banana-spotting bug.

\section{Acknowledgments}

Geoff Waite, now retired from DEEDI, collaborated in much of the earlier work on Amblypelta pheromones and should be acknowledged for his contributions in this area. Robert Bauer (DEEDI) assisted with the field trials of the pheromones in north Queensland and the Australian Centre for International Agricultural Research provided funds in support of this work.

\section{References}

[1] G. Waite, "Amblypelta spp. (Hemiptera: Coreidae) and green fruit drop in lychees," Tropical Pest Management, vol. 36, pp. 353-355, 1990.

[2] G. Waite, H. Fay, and J. Rogers, "Fruitspotting bug in northeastern Australia," Workshop Report CTPM/DPI, Mareeba, Australia, July 1993.

[3] M. Ryan, "Damage to pawpaw trees by the banana-spotting bug, Amblypelta lutescens lutescens (Distant) (Heteroptera: Coreidae), in North Queensland," International Journal of Pest Management, vol. 40, pp. 280-282, 1994.

[4] H. Fay, "Fruitpiercing moths and fruitspotting bugs: intractable pests of tree fruits in a reduced insecticide environment," Acta Horticulturae, vol. 575, no. 2, pp. 485-493, 2002.

[5] H. Drew, "Improving the management of spotting bugs in avocados," Manual Produced as Part of HAL Project AVO6001, HAL/Avocados Australia, 2007.
[6] J. R. Aldrich, G. K. Waite, C. Moore, J. A. Payne, W. R. Lusby, and J. P. Kochansky, "Male-specific volatiles from nearctic and Australasian true bugs (Heteroptera: Coreidae and Alydidae)," Journal of Chemical Ecology, vol. 19, no. 12, pp. 2767-2781, 1993.

[7] H. Kigoshi, M. Ojika, Y. Shizuri, H. Niwa, and K. Yamada, "Isolation of $(10 R, 11 R)-(+)$-squalene-10,11-epoxide from the red alga Laurencia okamurai and its enantioselective synthesis," Tetrahedron, vol. 42, no. 14, pp. 3789-3792, 1986.

[8] J. A. Spicer, M. A. Brimble, and D. D. Rowan, "Oxidation of $\alpha$ farnesene," Australian Journal of Chemistry, vol. 46, pp. 19291939, 1993.

[9] S. Yamada, H. Ohsawa, T. Suzuki, and H. Takayama, "Stereoselective synthesis of $(E)$-, $(E, Z)$-, and $(E, E)$-conjugated dienes via alkylation of 3 -sulfolenes as the key step," Chemistry Letters, vol. 12, pp. 1003-1006, 1983.

[10] S. R. Desai, V. K. Gore, and S. V. Bhat, "Highly stereoselective synthesis of $\alpha$-sinensal and trans- $\beta$-ocimenal," Synthetic Communications, vol. 20, pp. 523-533, 1990.

[11] T.-S. Chou, H.-H. Tso, and L.-J. Chang, "Stereoselective onestep syntheses of trans- $\beta$-ocimene and $\alpha$-farnesene," Journal of the Chemical Society, Chemical Communications, no. 20, pp. 1323-1324, 1984.

[12] S. Yamada, H. Ohsawa, T. Suzuki, and H. Takayama, "Stereoselective synthesis of $(E)$-, $(E, Z)$-, and $(E, E)$-conjugated dienes via alkylation of 3 -sulfolenes as the key step," Journal of Organic Chemistry, vol. 51, no. 25, pp. 4934-4940, 1986.

[13] K. B. Sharpless, W. Amberg, Y. L. Bennani et al., "The osmiumcatalyzed asymmetric dihydroxylation: a new ligand class and a process improvement," Journal of Organic Chemistry, vol. 57, no. 10 , pp. $2768-2771,1992$.

[14] M. A. Brimble, D. D. Rowan, and J. A. Spicer, "Synthesis of chiral hydroxylated farnesene derivatives," Synthesis, no. 1, pp. 116-122, 1996.

[15] S. Fielder and D. D. Rowan, "The synthesis of $\mathrm{d}_{6}-\alpha$-farnesene," Journal of Labelled Compounds and Radiopharmaceuticals, vol. 34, no. 11, pp. 1075-1085, 1994.

[16] A. Khrimian, P. W. Shearer, A. Zhang, G. C. Hamilton, and J. R. Aldrich, "Field trapping of the invasive brown marmorated stink bug, Halyomorpha halys, with geometric isomers of methyl 2,4,6-decatrienoate," Journal of Agricultural and Food Chemistry, vol. 56, no. 1, pp. 197-203, 2008.

[17] VSN International, Genstat, Hemel Hempstead, Hertfordshire, UK, 11th edition, 2008.

[18] C. J. Moore, S. Possner, P. Hayes, G. C. Paddon-Jones, and W. Kitching, "An asymmetric dihydroxylation route to $(3 R, 5 E)$ 2,6-dimethyl-2,3-epoxyocta-5,7-diene: the major volatile component from male fruit-spotting bugs," Journal of Organic Chemistry, vol. 64, no. 26, pp. 9742-9744, 1999. 
[19] G. A. Crispino and K. B. Sharpless, "Asymmetric dihydroxylation of squalene," Tetrahedron Letters, vol. 33, no. 30, pp. 42734274, 1992.

[20] G. Frater and U. Müller, "Synthesis of $(+)-(4 S, 8 R)-8$-epi- and (-)-(4R,8S)-4-epi- $\beta$-bisabolol," Helvetica Chimica Acta, vol. 72, pp. 653-658, 1989.

[21] J. Šobotník, R. Hanus, B. Kalinová et al., “( $E, E)-\alpha$-farnesene, an alarm pheromone of the termite Prorhinotermes canalifrons," Journal of Chemical Ecology, vol. 34, no. 4, pp. 478-486, 2008. 

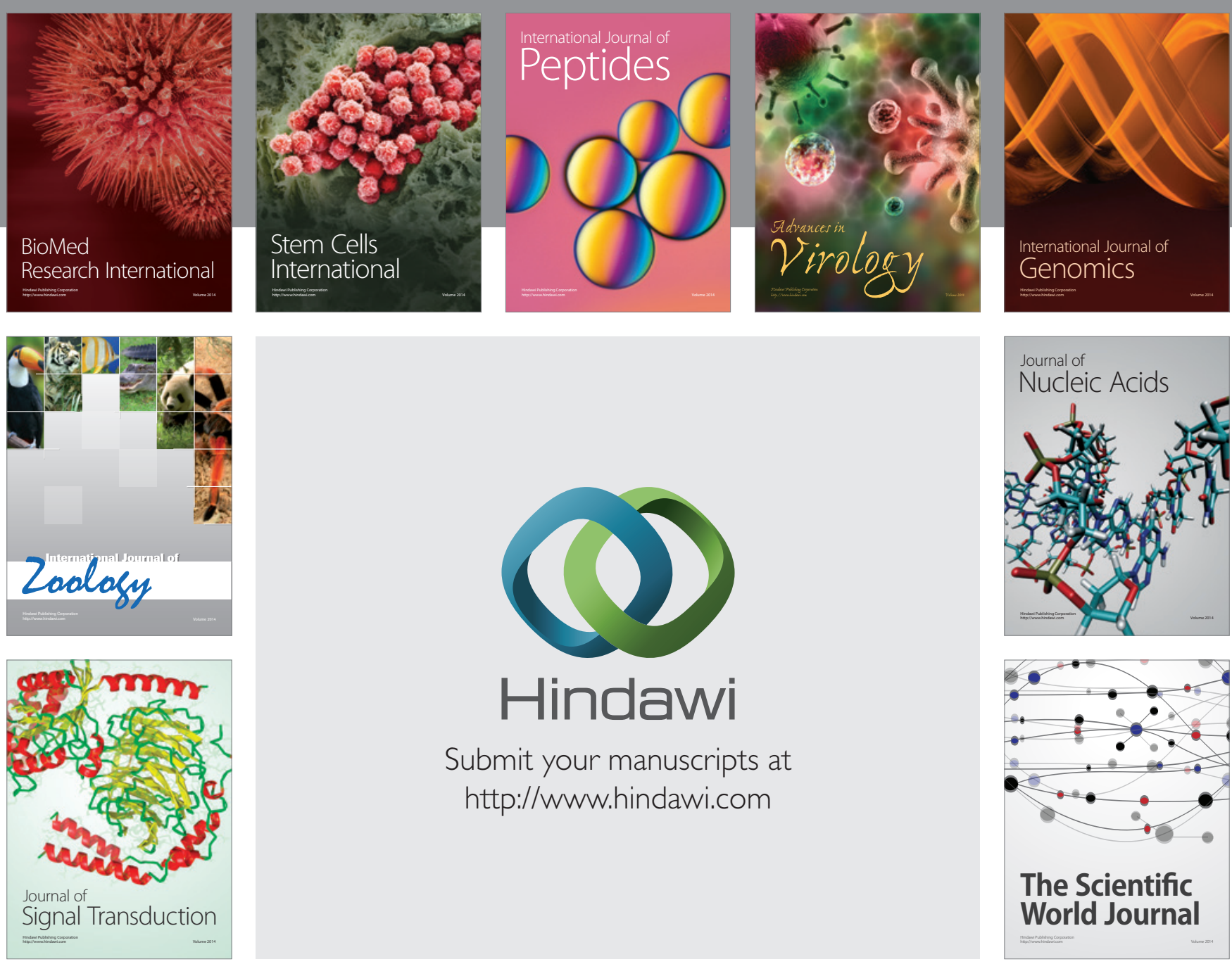

Submit your manuscripts at

http://www.hindawi.com
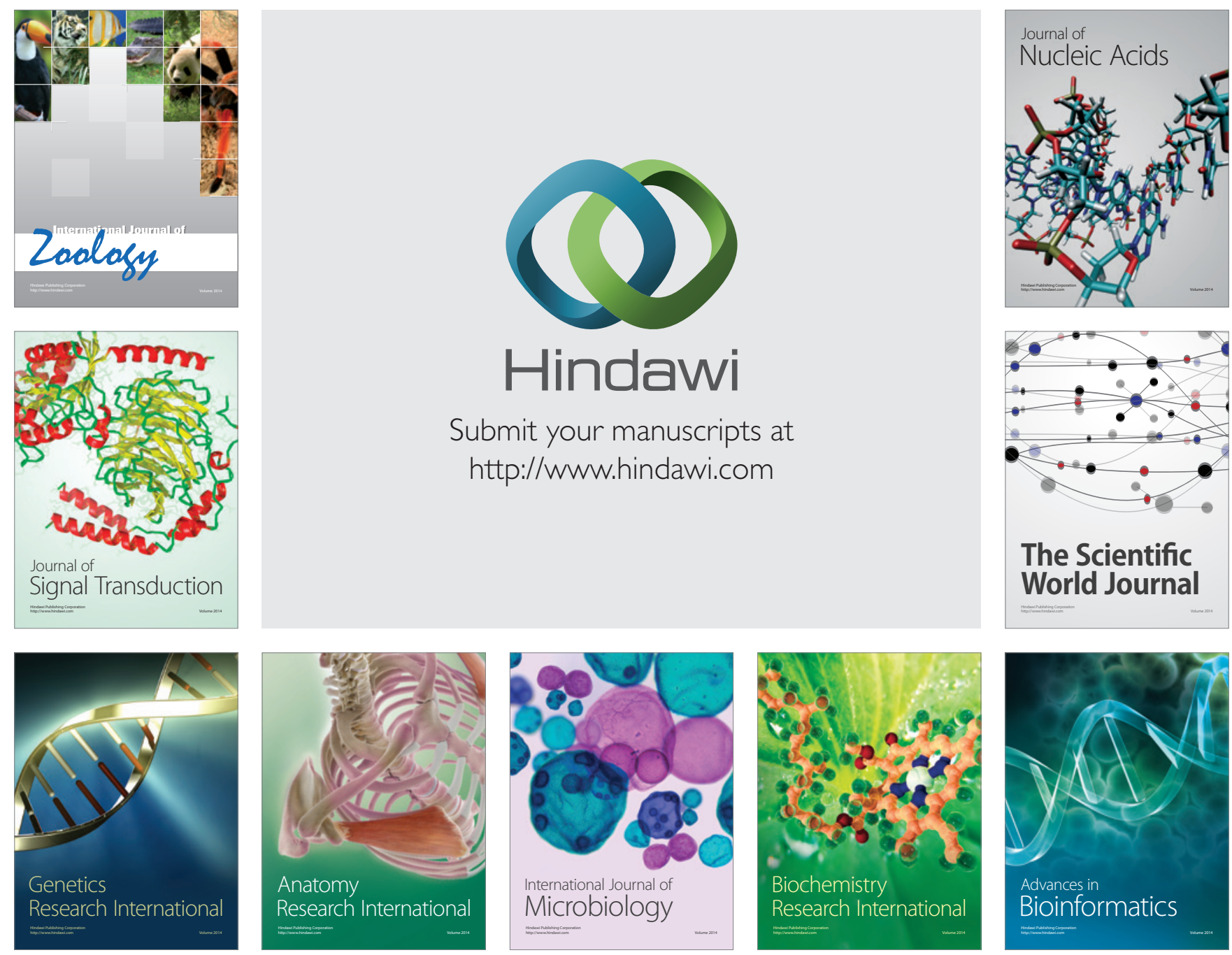

The Scientific World Journal
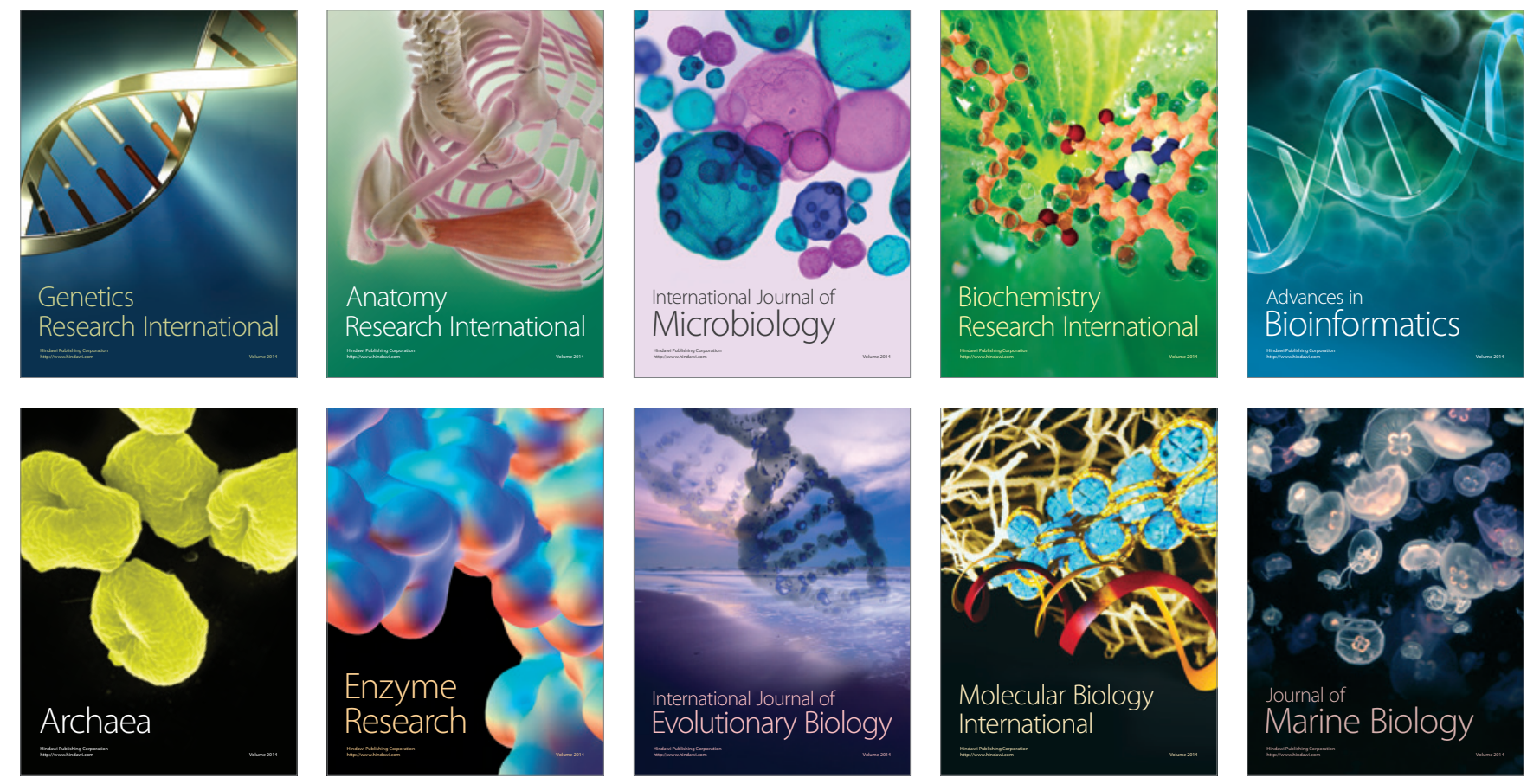